\title{
Analysis of Factors Affecting Taxpayer Compliance Paying Hotel Tax, Restaurant Tax and Entertainment Tax in Medan City
}

\author{
Mahyuliza $^{1}$, M. Fitri Rahmadana ${ }^{2}$, Eko Wahyu Nugrahadi ${ }^{3}$ \\ 1,2,3 Universitas Negeri Medan, Indonesia \\ mahyuliza12@gmail.com
}

\begin{abstract}
Regional tax revenue in Medan City as a source of financing has increased quite significantly, therefore local taxes remain the prima donna for financing regional expenditures in Medan City. For the Government of Medan City, although the fiscal capacity that comes from local revenue is still limited, local taxes still play an important role in increasing tax revenue in Medan City. Based on Law Number 28 Year 2011, hotel, restaurant and entertainment tax collection implements a self-assessment system so that taxpayer awareness is a very determining factor for taxpayer compliance in carrying out tax obligations and rights. This study aims 1) to analyze the effect of tax knowledge, service quality, tax audit on taxpayer awareness of paying hotel taxes, restaurant taxes and entertainment taxes in Medan City; 2) to analyze the effect of tax knowledge, service quality, tax inspection and taxpayer awareness on taxpayer compliance of paying hotel taxes, restaurant taxes and entertainment taxes in Medan City. The research method used is quantitative research methods. There are two sources of data used, namely primary data and secondary data obtained from the Medan City Revenue Service. The data collection method used was a questionnaire. Sampling was done by accidental sampling. The analytical tool used is descriptive analysis and path diagram analysis. The results of hypothesis testing carried out by path analysis show that 1) tax knowledge, service quality and tax audits have a positive effect on taxpayer awareness of paying hotel taxes, restaurant taxes and entertainment taxes in Medan City; 2) service quality and tax audits have no effect on taxpayer compliance paying hotel, restaurant and entertainment taxes in the city of Medan, while tax knowledge tax inspection and taxpayer awareness have a positive effect on taxpayer compliance paying hotel taxes, restaurant taxes and entertainment taxes in Medan city; because the amount of hotel tax revenue, restaurant tax and entertainment provide a high contribution to local taxes in Medan City.
\end{abstract}

Keywords

compliance, tax knowledge; service quality, tax audit

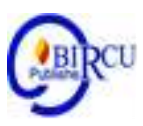

\section{Introduction}

Medan City as a domestic and foreign tourist destination must also be ready with supporting facilities and infrastructure, both hotels, restaurants and entertainment. Tourists who come to Medan usually stay in a place that has adequate facilities. Hotels, restaurants and entertainment are one of the supporting facilities for the economy and tourism. Regional tax revenue originating from hotel taxes, restaurant taxes and entertainment taxes in Medan City as a source of financing has increased quite significantly, therefore this regional tax remains the prima donna for financing regional expenditures in Medan City. 
For the Medan City Government, although the fiscal capacity that comes from its own local revenue is still limited, local taxes still play an important role. Hotel tax, restaurant tax and entertainment tax are types of regional taxes that have the same characteristics, where the taxpayer is an individual or entity that has a business in the hotel, restaurant or entertainment sector which is subject to tax objects or any services that have been provided to customers. . Based on Law Number 28 of 2009 concerning Regional Taxes and Regional Levies, hotel taxpayers, restaurant taxpayers and entertainment taxpayers have the right to collect taxes on services provided to consumers and have the obligation to report and pay these taxes to the Regional Government. Hotel tax, restaurant tax and entertainment tax are local taxes imposed on tax subjects, namely consumers who have enjoyed services. The tax that has been collected by the taxpayer must be reported and remitted by the taxpayer to the Regional Government.

Adhering to the self-assessment system brings the mission and consequences of changing attitudes (awareness) that occur in the community to pay taxes voluntarily (Darmayanti, 2004). The level of taxpayers in complying with their tax obligations is influenced by several factors, one of which is the awareness of taxpayers. An understanding of taxes and the seriousness of taxpayers to report and pay their tax obligations can reflect the level of awareness of taxpayers. If public awareness of taxation is still low, it will cause a lot of tax potential that cannot be utilized.

Table 1.Amount of Arrears for Hotel Tax, Restaurant Tax and Entertainment Tax in 2015 2019

\begin{tabular}{cccc}
\hline Year & $\begin{array}{c}\text { Hotel Tax } \\
\text { (IDR) }\end{array}$ & $\begin{array}{c}\text { Restaurant tax } \\
\text { (IDR) }\end{array}$ & $\begin{array}{c}\text { Entertainment Tax } \\
\text { (IDR) }\end{array}$ \\
\hline 2015 & $10.024 .478 .728,93$ & $10.575 .004 .675,39$ & $1.388 .954 .030,96$ \\
2016 & $10.369 .603 .475,52$ & $11.846 .377 .247,14$ & $1.647 .175 .063,20$ \\
2017 & $13.860 .615 .923,30$ & $10.978 .084 .264,59$ & $6.077 .540 .192,16$ \\
2018 & $15.860 .611 .432,63$ & $11.414 .372 .598,85$ & $5.712 .381 .728,16$ \\
2019 & $17,424,976,740,76$ & $10.937 .061 .634,26$ & $4.019 .783 .719,16$
\end{tabular}

Source: Regional Tax and Retribution Management Agency (BPPRD), 2020

The level of compliance of taxpayers for hotels, restaurants and entertainment in Medan City to make payments is still low, this can be seen from the not optimal tax revenue and there are still tax arrears every year. Tax arrears are the amount of tax payable that has not been paid by taxpayers. These arrears are caused by an inspection by the tax authorities or because taxpayers have not paid their taxes.

Based on Table 1 the amount of arrears for hotel taxes, restaurant taxes and entertainment taxes which continue to increase every year from 2015 to 2019, this indicates that taxpayers' awareness of tax compliance is still low. Tjaraka (2007) states that taxpayer compliance is influenced by many factors, including the condition of a country's tax administration system, services to taxpayers, tax law enforcement, tax audits and tax rates. Some of these factors need continuous attention and improvement so that the achievement of improvements in taxpayer compliance can be realized.

Taxpayer compliance is strongly influenced by the awareness of taxpayers. This is because paying taxes is an activity that cannot be separated from the condition of the taxpayer's behavior itself. Taxpayer awareness regarding moral aspects in the field of taxation involves two things, namely (1) the moral obligations of taxpayers in carrying out their tax obligations as good citizens and (2) concerning the moral awareness of taxpayers on the allocation of tax revenue by the government (Troutman, 1993). 
One of the elements emphasized by the authorities in increasing tax awareness and compliance is by socializing tax regulations, both through counseling, moral exclamations using billboards, and opening a tax regulation site that can be accessed by taxpayers at any time, so that with this socialization knowledge taxpayers to their tax obligations are getting higher. Knowledge of tax regulations is important to cultivate obedient behavior because how can taxpayers be asked to comply if they do not know how tax regulations are.

Widayati (2010) states that taxpayers who have good knowledge will have a positive perception of the tax system which results in a higher level of tax compliance. The level of tax compliance is also influenced by the quality of service. The better the quality of service, the higher the level of taxpayer compliance. Research conducted by Rizki (2012) concluded that there was a positive and significant effect of service quality on the level of tax compliance. Taxpayer communities will tend to increase tax compliance if they are satisfied with the services provided by tax officers in serving their needs while processing taxes.

Based on the explanation above, to find out the increase in tax revenue in Medan City, in order to be more transparent, honest, democratic, effective, efficient, and accountable, the authors are interested in researching about "Analysis of Factors Affecting Taxpayer Compliance Paying Hotel Taxes. Restaurant Tax and Entertainment Tax in Medan City".

\section{Review of Literatures}

\subsection{Definition of Tax}

According to Soemitro (2004) Tax is the transfer of wealth from the people to the State treasury to finance routine expenses and the surplus is used for public saving which is the main source of financing public investment. The definition of tax given by Soeparman (1964) states that, Tax is a transfer of sources from the private sector to the government sector, not the result of a violation of the law, but must be implemented, based on the provisions previously determined, without receiving direct and proportional compensation, so that the government can carry out their duties to run the government.

Based on the definition of tax above, both in terms of economics (tax as a transfer of sources from the public sector to the government sector) or juridical understanding (tax is a contribution that can be enforced), it can be concluded about the characteristics contained in the definition of tax as follows:

1) Taxes are collected by the State both by the central government and regional governments based on the law and implementing regulations.

2) Tax collection implies the transfer of funds (resources) from the private sector (taxpayers paying taxes) to the government sector (tax collectors).

3) Tax collection is intended for general government financing purposes in the framework of carrying out government functions both routine and development.

4) It cannot be shown that there is an individual compensation (counter-achievement) by the government for tax payments made by the taxpayer.

Tax is a compulsory levy paid by the people to the state and will be used for the benefit of the government and the general public. People who pay taxes will not feel the benefits of taxes directly, because the tax is used for public purposes, not for personal gain. Taxes are one source of government funds for development, both the central and regional governments. Tax collection can be forced because it is carried out according to the law. (Siregar et al, 2019. Tax is a public contribution to the State treasury (transfer of private sector wealth to the law) based on the Act (can be forced) with no reciprocal services (tegen prestatie) which can be directly demonstrated and used to finance public expenditure (publieke uitgaven). (Marpaung, 2020). 


\subsection{Local Tax}

Regional taxes are taxes collected by regions such as provinces and regencies / cities and the proceeds are used to finance regional households. Local taxes are collected based on Law Number 28 of 2009, on the amendment to Law Number 34 of 2000 which was previously Law Number 18 of 1997 concerning Regional Taxes and Regional Levies, as well as types of Regional Taxes, namely

1) Provincial taxes consist of:

a. Vehicle tax;

b. Motorized Vehicle Name Medank Fee;

c. Motor Vehicle Fuel Tax;

d. Surface Water Tax; and

e. Cigarette Tax.

2) Types of Regency / City taxes consist of:

a. Hotel Tax;

b. Restaurant tax;

c. Entertainment Tax;

d. Advertisement tax;

e. Street Lighting Tax;

f. Non-Metal Mineral and Rock Tax;

g. Parking Tax;

h. Groundwater Tax;

i. Swallow's Nest Tax;

j. Rural and Urban Land and Building Tax;

$\mathrm{k}$. Fees for Acquisition of Rights to Land and Buildings.

In connection with the authority given to local governments to impose a type of tax, the regional government must first issue a regulation on regional taxes. The regulation will become the operational legal basis in the technical implementation of the imposition and collection of relevant regional taxes.

\subsection{Hotel Tax}

Hotel tax is a tax on services provided by hotels. The definition of a hotel is a facility for providing lodging or resort services including other related services for a fee, which includes motels, inns, tourist huts, tourism guesthouses, guesthouses, lodging houses and the like as well as boarding houses with more than 10 rooms.

Hotel tax collection in Indonesia is currently based on a clear and strong legal basis so that it must be obeyed by the public and related parties. The legal basis for collecting Hotel Taxes in Medan City is Law Number 28 of 2009, PP Number 65 concerning regional taxes and Regional Regulation of Medan City Number 5 of 2011. Hotel taxpayers include individuals or entities that operate hotels. Hotel taxpayers are obliged to collect hotel tax objects. Hotel taxpayers are required to record, report and pay the taxes they receive from customers. Hotel tax subjects include individuals or entities that make payments to individuals or entities that operate hotels. The object of hotel tax is any service provided by payment or which should be paid at the hotel, which includes, among others.

a) Lodging facilities or short-term stay facilities;

b) Supporting services that provide convenience and comfort for lodging or short-term stay facilities;

c) Sports and entertainment facilities provided specifically for hotel guests, not for the public;

d) Room rental services for events or meetings at the hotel

The basis for the imposition of hotel taxes is the amount of payment or payments that should be made to the hotel. The hotel tax rate is set at 10 percent of the total payment. 


\subsection{Restaurant Tax}

Restaurants, according to Law Number 28 of 2009 are facilities for providing food or drinks for free, which include restaurants, catering, stalls, bars and the like including catering services. Restaurant tax is a tax on services provided by restaurants. The legal basis for restaurant tax in Medan is Law Number 28 of 2009 and Regional Regulation of Medan City Number 5 of 2011. A restaurant taxpayer is an individual or entity that operates a restaurant. Restaurant tax subjects are private persons or entities that purchase food or drinks from restaurants. The object of restaurant tax is in the form of services provided by the restaurant. The services provided by the restaurant as intended include services for the sale of food or drinks that are consumed by the buyer, whether consumed at the service place or elsewhere. The tax base is in the form of the amount of payment received or that should be received by the restaurant. The tax rate is set at ten percent. The amount of tax payable is calculated by multiplying the tax rate by the tax base.

\subsection{Entertainment Tax}

Entertainment tax is a tax on the organization of entertainment. The legal basis for entertainment tax in Medan is Law Number 28 of 2009 and Regional Regulation of Medan City Number 8 of 2016. Entertainment taxpayers include individuals or entities that organize entertainment. The subject of entertainment tax includes individuals or entities who enjoy entertainment. The object of entertainment tax is in the form of free entertainment services.

The basis for the imposition of entertainment tax is in the form of the amount paid or that should be paid for watching or enjoying entertainment. The entertainment tax rate is set at ten percent. The amount of tax owed is calculated by multiplying the tax rate by the tax base.

\subsection{Tax Compliance}

Compliance according to the large Indonesian dictionary means submitting or obeying teachings or regulations. According to Gunadi (2005), tax compliance can mean that taxpayers have the willingness to fulfill their tax obligations in accordance with applicable regulations without the need for examination, careful investigation, warnings or threats and the application of administrative sanctions. According to Nurmantu (2005), tax compliance is defined as a condition in which the taxpayer fulfills all tax obligations and exercises his taxation rights.

According to Chaizi (2005), taxpayer compliance can be identified from taxpayer compliance in registering, compliance to deposit tax notification letters, compliance in calculating and paying taxes owed and compliance in paying arrears.

\subsection{Taxpayer Awareness}

Irianto (2005) in Widayati and Nurlis (2010) describes several forms of awareness that encourage taxpayers to pay taxes, namely.

1) Awareness that taxes are a form of participation in supporting state development. By realizing this, taxpayers are willing to pay taxes because they feel they are not disadvantaged from the tax collection that is carried out. It is realized that taxes are used for state development in order to improve the welfare of citizens.

2) Awareness that postponing tax payments and reducing tax burdens is very detrimental to the state. Taxpayers are willing to pay taxes because they understand that delays in paying taxes and reducing tax burdens have an impact on a lack of financial resources which can hamper the country's development.

3) Awareness that taxes are established by law and can be enforced. Taxpayers will pay because it is recognized that paying taxes has a strong legal basis and is an absolute obligation of every citizen. 
4) Consciousness is an element in humans in understanding reality and how to act or respond to reality. The awareness possessed by humans is awareness within oneself, of others, the past and the possible future.

\subsection{Tax Knowledge}

There are several indicators that taxpayers know and understand tax regulations Menururt Burton (2008). First, the ownership of Regional Taxpayer Identification Number (NPWPD). Every taxpayer who has a business in the fields of hospitality, restaurants and entertainment is obliged to register to obtain an NPWPD as a means of tax administration.

Second, knowledge and understanding of the rights and obligations as taxpayers. If taxpayers know and understand their obligations as taxpayers, then they will do so, one of which is paying taxes. Third, knowledge and understanding of tax sanctions. The more know and understand taxpayers about tax regulations, the more they will know and understand the taxpayers about the sanctions they will receive if they neglect their tax obligations. This of course will encourage taxpayers to carry out their obligations. Fourth, knowledge and understanding of applicable tax rates. By knowing and understanding the applicable tax rates, it will encourage taxpayers to be able to calculate their own tax obligations correctly. Fifth, taxpayers know and understand tax regulations through tax socialization carried out by related agencies.

\subsection{Service Quality}

The definition of service is a process of helping others in certain ways that require sensitivity and interpersonal relationships in order to create satisfaction and success (Yudi, 2007). Service quality is a comparison between what customers want about their assessment of the actual performance of a service provision. Agustini (2008) states that there are five dimensions to evaluate service quality, namely:

1) Direct Evidence, which includes physical facilities, employees, equipment and communications.

2) Reliability is the ability of officers to provide promising services immediately and on target

3) Responsiveness is a characteristic of suitability in human services, namely the desire of tax officers to help taxpayers and provide responsive services.

4) Assurance, which includes the ability, decency and trustworthiness of the tax officer to be free from risk, danger or doubt.

Empathy which includes the ease with which officers make good communication relationships and understand taxpayers.

\subsection{Tax Audits}

Tax audit is a series of activities to collect and process data, information and / or evidence carried out objectively and proportionally to an audit standard to test compliance with taxation obligations and / or for other purposes in the context of implementing the provisions of tax laws.

Tax audit (John, 2007) includes activities to find, collect and process data and or other information that comes from the taxpayer's books and from or from other sources that can be used to determine the actual tax obligations of the taxpayer. Another definition of tax audit (Soemarso, 2007) is a series of activities carried out by the tax office on taxpayers to seek and collect data or other information in order to determine the amount of tax owed and or for other purposes in the implementation of statutory provisions. 


\section{Research Methods}

This research was conducted at the Regional Tax and Retribution Management Agency of Medan City. The data in this research concerns, among others: data on the number of hotel taxpayers, restaurant taxpayers and entertainment taxpayers, hotel tax realization and arrears data, restaurant tax and entertainment tax obtained at the Regional Tax and Retribution Management Agency. This study uses questionnaires and in-depth interviews given to taxpayers and public officials who know the problems to be studied. The data sources of this research are respondents, namely taxpayers who are randomly selected. The primary data needed in this study are data related to the variables of tax knowledge, service quality, tax inspection, taxpayer awareness and taxpayer compliance of paying hotel taxes, restaurant taxes and entertainment taxes in Medan City. Secondary data used in this study were collected through the necessary data and sourced from the Regional Tax and Retribution Management Agency (BPPRD) such as data on the number of taxpayers for hotels, restaurants and entertainment, data on local revenue and regional tax arrears in Medan City. This population is the hotel taxpayer, restaurant taxpayer and entertainment taxpayer in Medan City in 2019, totaling 1155 taxpayers. Determination of the sample size in the study consisted of 109 hotel taxpayers, 147 restaurant taxpayers and 41 entertainment taxpayers. The instrument used in this study was a questionnaire that was structured based on the research objectives. The questionnaire is in the form of a respondent's statement about tax knowledge, service quality, tax audit, taxpayer awareness and compliance of paying hotel taxes, restaurant taxes and entertainment taxes in Medan City. The variable measurement scale used in this study is a Likert scale. Likert scale is used to measure attitudes, opinions, and perceptions of a person or group of people about social phenomena. The application of descriptive statistics in this research includes the calculation of the mean, standard deviation, tables, figures and so on which were made using the SPSS and Microsoft Excel programs. Calculating the value of Respondent Achievement Level (TCR) for each category. The formula used is (Riduwan, 2006: 88):

$$
\mathrm{TCR}=\frac{R s}{n} \times 100 \%
$$

Information:

TCR $=$ Respondent Achievement Level

Rs $=$ Average score of respondents' answers

$\mathrm{N}=$ Value of the answer score

Descriptive analysis method is an activity to conclude large amounts of raw data so that the results can be interpreted. Grouping or separating the relevant components or parts of the overall data is also a form of analysis to make data easy to manage. The purpose of the normality test is to determine whether the distribution of a data follows or approaches the normal distribution. The normality test is carried out using the Kolmogorov - Smirnov approach. By using a significant level of 5\%, if the Pvalue (Sig.) Value is above 5\% significant value, it can be concluded that the data is taken from a normally distributed population. The path analysis technique is used to test the amount of contribution (contribution) shown by the path coefficient on each path diagram of the causal relationship between variables $\mathrm{X} 1, \mathrm{X} 2, \mathrm{X} 3$ to $\mathrm{Y}$ and its impact on $\mathrm{Z}$. Path coefficient is calculated by making two structural equations, namely the regression equation that shows the hypothesized relationship. 


\section{Result and Discussion}

\subsection{The Effect of Tax Knowledge, Service Quality and Tax Audit on Taxpayers' Awareness}

of Paying Hotel Tax, Restaurant Tax and Entertainment Tax in Medan City

Based on the results of the analysis, it shows that tax knowledge, service quality and tax audits affect the awareness of taxpayers to pay hotel taxes, restaurant taxes and entertainment taxes in Medan City. This can be seen from the significance value of $0.000<0.05$, so that the hypothesis is accepted. With the coefficient of determination R2 t-statistic is located in the RSquare column. It is known that the coefficient of determination is 0.734 . This value means that all independent variables are able to explain the dependent variable (Taxpayer Awareness) of $73.4 \%$, while the remaining $27.6 \%$ is influenced by other factors. With the coefficient of determination R2 Path Analysis, it is known that the coefficient of determination is 0.4612 . This value means that all independent variables are able to explain the dependent variable (Taxpayer Awareness) of $46.12 \%$, while the remaining $53.88 \%$ is influenced by other factors. This shows that with increasing tax knowledge possessed by taxpayers and improving service quality by tax officers and supported by transparent tax audits, the awareness of hotel taxpayers, restaurant taxpayers and entertainment taxpayers in Medan is getting better.

The results showed that the tax knowledge variable has a positive effect on the awareness of taxpayers to pay hotel taxes, restaurant taxes and entertainment taxes in Medan City. Tax Knowledge Variable (X1) with t-statistical test value of 4,429. The results of research data processing indicate that the Tax Knowledge variable has a positive coefficient of 0.165 .

This means that if tax knowledge increases by $1 \%$, the awareness of taxpayers to pay taxes will increase by 0.165 . In addition, the Tax Knowledge Significance Value is 0.000 $<0.05$. Then the Tax Knowledge variable is at the level of $\alpha=5 \%$. This positive direction shows that the increase in Tax Knowledge for taxpayers, the awareness of taxpayers to pay taxes will increase. Likewise, on the contrary, the decrease in Tax Knowledge for taxpayers, the Taxpayer Awareness to pay taxes will decrease.

Knowledge is influenced by many things, including formal and non-formal education factors. A person's knowledge of an object contains two aspects, namely positive and negative aspects. These two aspects will determine a person's attitude, the more positive aspects the more positive towards certain objects (Fidel, 2004 in Ghoni, 2012). According to Nugroho (2012) the higher the knowledge and understanding of taxpayers, the taxpayers can better determine their behavior and in accordance with the provisions of tax regulations. However, if the taxpayer does not have knowledge of the tax regulations and processes, the taxpayer cannot determine his behavior appropriately in accordance with the applicable regulations. Efforts to increase taxpayer awareness so that taxpayers are increasingly compliant is by increasing knowledge in the field of taxation.

If a person or taxpayer has high knowledge of taxation, then they will be more aware in fulfilling their obligations. In an empirical study, Suparmono and Damayanti (2000) state that taxpayers must know the amount of tax owed, when to pay taxes and the deadline for payment. The results of this study are in line with research from Nugroho (2012) which states that knowledge and understanding of tax regulations have a positive and significant effect on taxpayer awareness in paying taxes.

The results also show that service quality has a positive and significant effect on the awareness of taxpayers to pay hotel taxes, restaurant taxes and restaurant taxes in Medan City. Service Quality Variable (X2) with a t-statistical test value of 10.018. The results of the research data processing indicate that the Service Quality variable has a positive coefficient of 0.396 . This means that if the quality of service increases by $1 \%$, the awareness of taxpayers to pay taxes will increase by 0.396. In addition, the Tax Knowledge Significance Value is 0.000 
$<0.05$. Then the Service Quality variable is at the level of $\alpha=5 \%$. This positive direction shows that the increasing quality of service for taxpayers, the awareness of taxpayers to pay taxes will increase. Likewise, the quality of service for taxpayers decreases, so the taxpayer's awareness to pay taxes will decrease. Based on the theory, it is stated that quality service according to Chen and Tan (2004) in Ussahawanichakit (2008) is a comparison between what the customer expects and what he gets. The results of this study are in line with previous research conducted by Arum (2012) which states that service quality has a significant effect on taxpayer awareness because tax authorities are expected to have an understanding of taxation and also have high motivation as public servants so that taxpayers feel comfortable every time they carry out tax activities at the tax service office.

The results of this study also indicate that the tax audit variable has a positive and significant effect on taxpayer awareness of paying hotel taxes, restaurant taxes and entertainment taxes in Medan City. Tax Audit Variable (X3) with a t-statistical test value of 10,937. The results of research data processing indicate that the Tax Audit variable has a positive coefficient of 0.439 . This means that if the Tax Audit increases by $1 \%$, the taxpayer's awareness of paying taxes increases by 0.496 . In addition, the Tax Knowledge Significance Value is $0.000<0.05$. Then the Tax Audit variable is at the level of $\alpha=5 \%$. This positive direction shows that the increasing quality of service for taxpayers, the awareness of taxpayers to pay taxes will increase. Likewise, the tax audit for taxpayers decreases, the taxpayers' awareness to pay taxes will decrease. This is in accordance with empirical evidence in previous research conducted by Salip and Wato (2006) which states that tax auditing will encourage taxpayer awareness so that it will have an impact on increasing tax revenue.

\subsection{The Influence of Tax Knowledge, Service Quality and Tax Audit and Taxpayer Awareness of Taxpayer Compliance with Paying Hotel Tax, Restaurant Tax and Entertainment Tax in Medan City}

The results of the analysis show that tax knowledge, tax audit service quality and taxpayer awareness have an effect on taxpayer compliance to pay hotel taxes, restaurant taxes and entertainment taxes in Medan City. This can be seen from the significance value of 0.000 $<0.05$, so that the hypothesis is accepted. With the coefficient of determination R2 t-statistic is located in the R-Square column.

It is known that the coefficient of determination is 0.519 . This value means that all independent variables are able to explain the dependent variable (Taxpayer Compliance) of $51.9 \%$, while the remaining $48.1 \%$ is influenced by other factors. With the coefficient of determination R2 Path Analysis, it is known that the coefficient of determination is 0.7306 . This value means that all independent variables are able to explain the dependent variable (Taxpayer Compliance) of $73.06 \%$, while the remaining $26.94 \%$ is influenced by other factors. This shows that with the increase in tax knowledge possessed by taxpayers and improved service quality by tax officers and supported by transparent tax audits and the level of awareness of the taxpayers to pay taxes, taxpayer compliance to pay hotel taxes, restaurant taxpayers and entertainment taxpayers in Medan City is getting better.

Tax Knowledge Variable (X1) with a Tax Knowledge Significance value of $0.000<0.05$. Then the Tax Knowledge variable is at the level of $\alpha=5 \%$. This positive direction shows that the increase in Tax Knowledge for taxpayers, the awareness of taxpayers to pay taxes will increase. Likewise, the decrease in Tax Knowledge for taxpayers will decrease the awareness of taxpayers to pay taxes.

Based on the theory put forward in Shcister (1995), it was found that there was a link between the level of knowledge of taxpayers on the increase in tax compliance. Ghoni (2012) which shows that tax knowledge has an effect on taxpayer compliance. Therefore, having 
sufficient knowledge about taxation is very important because tax education is one of the effective tools to encourage taxpayers to be more obedient in paying taxes.

The results of the research on service quality variables (X2) indicate that the service quality variable has no and insignificant effect on taxpayer compliance to pay hotel taxes, restaurant taxes and entertainment taxes in Medan City with the Tax Knowledge Significance value $0.305>0.05$. Then the Tax Knowledge variable is at the level of $\alpha=5 \%$. Service Quality variable has no effect on taxpayer compliance.

The results of the tax audit variable research (X3) indicate that the tax audit variable has no and insignificant effect on taxpayer compliance to pay hotel taxes, restaurant taxes and entertainment taxes in Medan City with a significant value of Tax Knowledge 0.933>0.05. Then the Tax Knowledge variable is at the level of $\alpha=5 \%$. Tax audit variable has no effect on taxpayer compliance.

The taxpayer awareness variable in this study has a positive and significant effect directly on taxpayer compliance with paying hotel taxes, restaurant taxes and entertainment taxes in Medan City. With a significance value of $0.000>0.05$. Then the Tax Knowledge variable is at the level of $\alpha=5 \%$. This positive direction shows that the increasing awareness of taxpayers in paying taxes, the awareness of taxpayers to pay taxes will increase, and vice versa, the awareness of taxpayers to pay taxes for taxpayers will decrease, so the awareness of taxpayers to pay taxes will decrease. .

These results indicate that taxpayer awareness is an important factor in determining compliance of hotel taxpayers, restaurant taxpayers and entertainment taxpayers. Increased awareness will lead to an increase in taxpayer compliance to pay hotel taxes, restaurant taxes and entertainment taxes in Medan City. This is in line with Arum's research (2012) which states that the higher the awareness, the higher the taxpayer compliance. The results of this study also strengthen Jatmiko's (2006) research which states that tax awareness has a positive effect on taxpayer compliance.

\section{Conclusion}

Based on the research results, it can be concluded that: 1)Tax knowledge, service quality and tax audit have a positive and significant effect partially and simultaneously on the awareness of taxpayers to pay hotel taxes, restaurant taxes and entertainment taxes in Medan City. This indicates that taxpayers have high knowledge and understanding of taxation and will be able to better determine their behavior in accordance with taxation provisions. Improved service quality by tax officers and supported by transparent tax audits will be able to raise awareness of taxpayers for hotels, restaurants and entertainment in Medan City. 2) Tax knowledge and awareness of taxpayers have a positive and significant effect on taxpayer compliance in paying hotel taxes, restaurant taxes and entertainment taxes in Medan City. Meanwhile, service quality and tax audit have no effect on taxpayer compliance in paying hotel taxes, restaurant taxes and entertainment taxes in Medan City. This shows that the increase in tax knowledge carried out by the tax authorities, increased awareness supported by greater knowledge of taxation will be able to increase taxpayer compliance in paying hotel taxes, restaurant taxes and entertainment taxes in Medan City. in Medan City. In implementing the self-assessment system, taxpayer awareness plays an important role in determining tax compliance. The results of this study state that taxpayer awareness partially mediates the relationship between tax knowledge variables, service quality and tax audits with taxpayer compliance to pay hotel taxes, restaurant taxes and entertainment taxes in Medan City. When the level of awareness of the taxpayer increases, this will encourage taxpayers to comply with paying taxes. 


\section{References}

Agustini. (2008). Meningkatkan Kepatuhan Wajib Pajak Melalui Kualitas Pelayanan. Jurnal Keuangan Publik, 7 (1).

Arum, H.P. (2012). Pengaruh Kesadaran Wajib Pajak, Pelayanan Fiskus, dan Sanksi Pajak Terhadap Kepatuhan Wajib PajakOrang Pribadi yang Melakukan Kegiatan Usaha dan Pekerjaan Bebas (Studi Di Wilayah KPP Pratama Cilacap). Journal of Accounting, 1 (1): $1-8$.

Burton, R. (2008). Kajian Aktual Perpajakan. Jakarta: Salemba Empat.

Chaizi N. (2004). Reformasi Administrasi Publik, Teori dan Praktik. Jakarta: Grasindo.

Darmayanti, T.W. (2004). Pelaksanaan Self Assesment System Menurut Wajib Pajak (Studi Kasus pada Wajib Pajak Badan Salatiga). Jurnal Ekonomi dan Binis, X (1): 108-109.

Ghoni, H.A. (2012). Pengaruh Motivasi dan Pengetahuan Wajib Pajak terhadap Kepatuhan Wajib Pajak Daerah. Jurnal Akuntansi UNESA, 1 (1).

Gunadi. (2005).Fungsi Pemeriksaan Terhadap Peningkatan Kepatuhan Pajak. Jurnal Perpajakan Indonesia, 4 (5):4-9.

Hutagaol, J. (2007). Strategi Meningkatkan Kepatuhan Wajib Pajak. Jakarta: Akuntabilitas.

Irianto, S.E. (2005). Politik Perpajakan: Membangun Demokrasi Negara. Yogyakarta: UII Press.

Jatmiko, A. N. (2006). Pengaruh Sikap Wajib Pajak pada Pelaksanaan Sanksi Denda, Pelayanan Fiskus, dan Kesadaran Perpajakan Terhadap Kepatuhan Wajib Pajak. Tesis. Semarang: Program Studi Magister Akuntansi Universitas Diponegoro.

Marpaung, A. (2020). Zakat Regulation as a Reduction of Income Tax in Indonesia. Budapest International Research and Critics Institute-Journal (BIRCI-Journal). P. 2109-2116

Nugroho, R.A. (2012). Faktor-faktor yang mempengaruhi Kemauan untuk MembayarPajak dengan Kesadaran Membayar Pajak Sebagai Variabel Intervening. Akuntansi Fakultas Ekonomi dan Bisnis, 1 (2).

Nurmantu, S. (2005). Pengantar Perpajakan Edisi Ketiga.Jakarta: Granit Palil.

Rizki, U.S. (2012). Pengaruh Faktor-Faktor Eksternal Terhadap Tingkat Kepatuhan Wajib Pajak di Lingkungan Kantor Pelayanan Pajak Pratama Serang. (tesis). Universitas Sultan Ageng Tirtayasa.

Siregar, R. et al. (2019). The Effect of Corporate Taxpayer Compliance, the Increase of Corporate Taxpayers' Number and Tax Audits on Income Tax Receipts of Article 25 with Taxation Sanctions as a Moderating Variable in KPP Pratama Medan Petisah. Budapest International Research and Critics Institute-Journal (BIRCI-Journal). P. 385-400.

Surjoputro, D.S. and Junaedi E.W. (2004). Menuju Sistem dan Administrasi Perpajakan Berkelas Dunia: Studi Perpajakan di Indonesia dengan Inspirasi Pengalaman Jepang, ed. Robert Pakpahan and toyomu Yuasa. Jakarta: JICA.

Soemarso, S.R. (2007). Pemeriksaan Pajak. Jakrta: Salemba empat.

Soemitro, R. (2004). Asas dan Dasar Perpajakan. Bandung: Eresco.

Soeparman, S. (1964). Pajak Berdasarkan Asas Gotong Royong. Jakarta: Universitas Indonesia.

Suparmono and Damayanti, T. (2000). Perpajakan Indonesia Mekanisme dan Perhitungan. Yogyakarta: Andi.

Tjaraka, H. (2007). Upaya-Upaya Mengoptimalkan Pajak: Fiskus Versus Wajib Pajak. Jurnal Keuangan.

Troutman, C.S. (1993). Moral commitment to Tax Compliance as Measured by The Development of Moral Reasoning and Attitutes The Fairness of Txe Tax Laws. Dissertation. Oklahoma State University, USA. 
Ussahawanichakit, P. (2008). Effect of Organizational Learning Culture on ServiceQuality and Performance of Thai Accounting Firms. International Journal of Business Research.

Widayati and Nurlis. (2010). Faktor -faktor yang Mempengaruhi Kemauan Untuk Membayar Pajak Wajib Pajak Orang Pribadi Yang Melakukan Pekerjaan Bebas (Studi Kasus pada KPP Pratama Gambir Tiga): Simposium Nasional Akuntansi XIII Purwokerto 2010.

Yudi C.T. (2007). Peran Perpustakaan Sekolah dalam Mencetak Siswa Berprestasi. Jurnal Perpustakaan Sekolah. 1(1):1-13. 